\title{
多次元項目反応モデルにおけるプロクラステス回転を応用した 共通受検者による等化法の比較
}

\author{
沖嘉 訓, 前川眞一 \\ Comparison of Equating Methods for Multidimensional Item Response Theory \\ on Common Examinee Design with Factor Score Procrustes Rotation
}

Yoshinori OKI and Shin-ich MAYEKAWA

\begin{abstract}
Multidimensional item response theory model (MIRT) is a sub-model of Item Response Theory (IRT). It assumes that multidimensional latent traits influence test item responses. Equating or linking, which calibrate the parameters of two or more tests, are critical to the application of IRT, because they allow for comparisons between test scores. However, little research has been conducted for MIRT equating, especially on the common examinee design. The present study describes three equating methods for MIRT, which utilizes rotation methods in factor analysis focusing on factor scores, by employing the common examinee design, and analyzes the characteristics of each method through computer simulations. The results of the simulations reveal that the Weighted Procrustes method is effective when correlations between equated scores of each dimension are expected to approximate the target ones.

Key words: IRT, MIRT, equating, linking, common examinee design, factor analysis, weighted Procrustes rotation

キーワード：項目反応理論，多次元項目反応モデル，等化，共通受検者，因子分析，重み 付きプロクラステス回転
\end{abstract}

\section{1. はじめに}

項目反応理論 (項目応答理論, Item Response Theory, e.g. Lord, 1980, 芝, 1991, 村木, 2011, 豊田, 2012， 加藤・山田・川端, 2014 ：以下 IRT）は，テストを構 成する各問題項目について, 受検者の能力と問題項目 の特性の間にある種の確率的関数関係を仮定し，それ によってテストの特性と同時に受検者の能力を推定し ていこうとする理論モデル (池田, 2001) であり, 個人 の能力とテストの問題項目の特性を独立なものとして 考え, 各問題項目の特性を受検者集団に依存しない形

東京工業大学大学院社会理工学研究科人間行動システム 専攻

(Tokyo Institute of Technology)

連絡先： $=152-8550$ 東京都目黒区大岡山 $2-12-1$

Tel/Fax : 03-5734-3242

E-mail : okiyoshinori@gmail.com
で，また受検者の能力評価を問題項目の特性に依存し ない形で捉える点に特徵がある (仁田・前川・柳本・前

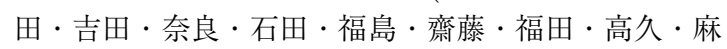
生, 2005).

IRT には項目に対する回答の形式や, 受検者の能力 特性と項目に対する反応の関係をどのように捉えるか ということに対応して，いくつかの下位モデルが開発さ れている (e.g. van der Linden \& Hambleton (Ed.), 1997). このうち多次元項目反応モデル (Multidimensional Item Response Theory Model, Reckase, 1985, Reckase \& McKinley, 1991, Reckase, 2009 : 以下多 次元 IRT）は, 項目に対する回答の背後に複数の能力 の関与を想定し, 受検者を多次元の潜在空間における 能力特性值ベクトルとして位置づけるモデルである.

Ackerman, Gierl \& Walker (2005) や Yao \& Boughton (2009) などが指摘するように, 多くのテ ストの回答の背後には多次元性が内在していると考え 
られる. たとえば学力テストにおいて, 数学の問題の 一部に文章題が含まれており，正答のために計算能力 に加えて文章理解能力も必要とされるような場合には, 回答の背後に多次元の能力特性を想定するのが自然で ある (孫, 1997). また, 性格検査において, 測定対象 の 2 つの性格特性に対応した短文を対にしてどちらが あてはまるかを問う形式や, 複数の性格特性について 自分にあてはまる順序を問う形式が利用されることが あるが，この場合は明らかに回答に複数の特性が同時 に関与しており，多次元 IRT を利用することが妥当 である (Brown \& Maydeu-Olivares, 2010, Brown \& Maydeu-Olivares, 2012).

さて, IRT の重要な研究テーマの一つに複数のテス トのスコアを同一の基準の上で比較可能とする等化法 に関する研究があり, 本邦においても積極的な研究が進 められている (e.g. Arai \& Mayekawa, 2011, 荒井・菊 池·前川, 2013, 泉 ·山野井·山田・金森·対馬, 2012, 光 永·前川, 2013, 光永 ·御園 · 水町, 2013). 多次元 IRT においても，等化に関する研究はやはり高い重要性を もつと考えられるが，その一方で Min (2007), Simon (2008) は多次元 IRT の等化法の研究が十分でないこ とを指摘している.

多次元 IRT の主な等化法には, 対象となるテスト . フォームに共通して含まれる項目群である共通項目を 利用する方法と， 2 つのテスト・フォームの両方を受 検した共通受検者の能力特性值を利用する方法がある (Reckase, 2009) ${ }^{1)}$. このうち, 共通項目による等化に ついては, 1 次元の IRT の場合の Stocking \& Lord 法 (Stocking \& Lord, 1983) を多次元に拡張した方 法 (Oshima, Davey \& Lee, 2000), Haebara 法 (Haebara, 1980) を多次元に拡張した方法 (Oshima, et al., 2000) などが提案されており, 加えて多次元 IRT に固 有の方法 (Li \& Lissitz, 2000, Min, 2007) も開発され ている．もう一方の共通受検者による等化法に関する 研究としては Hirsch によるもの (Hirsch, 1989) を挙 げることができるが，その他にほとんど見あたらず，共 通項目による等化法に関する研究に比べると非常に少 ないのが現状である.

しかしながら, 実際のテストの運用においては共通 項目の項目特性値をテストフォーム間で近接させるこ

1) 他に Reckase (2009) では, ランダムサンプリングし た受検者群の回答データを用いて共通項目や共通受検 者のデー夕を利用せずに等化を行う方法が紹介されて いる.
とよりも, 共通受検者の能力特性値を近接させること の重要性のほうが高い場面もある。したがって, 共通 受検者による等化法を整備することの必要性は小さく ないものと思われる.

ところで, 多次元 IRT は項目反応が離散的な值を取 る場合に対応した因子分析であると捉えることができる (Takane \& Leeuw, 1987, Muraki \& Carlson, 1995). 因子分析では通常, 潜在的な因子と項目との関連性が 興味の中心となることから, 回転法は専ら因子負荷量 に注目する形で構成されている。一方, 多次元 IRT の 共通受検者の能力特性値による等化は, 因子分析の文脈 では因子スコアに注目した回転に相当する。本研究で は多次元 IRT の共通受検者の能力特性值による等化法 として因子スコアに注目した回転法を示す。また, 計 算機を用いたシミュレーション的な実験を行いて，そ の特徴を明らかにする。

\section{2. 多次元項目反応モデル}

回答データの形式や能力特性の各次元と項目への反 応の関係をどのように捉えるかということに対応して, 多次元 IRT にはいくつかの下位モデルが開発されてい る (e.g. 藤森, 1988, Reckase, 2009, 岡田, 2014). この うち最もよく取り上げられ研究されているのは正誤 2 值データに対応した次の 2 パラメータ・ロジスティック 補償型モデル (two-parameter logistic compensatory model, Reckase, 2009) であると思われる. 本研究で も,このモデルについて検討する ${ }^{2)}$.

$$
P\left(x_{i j}=1 \mid \boldsymbol{a}_{j}, d_{j}, \boldsymbol{\theta}_{i}\right)=\frac{\exp \left(\boldsymbol{a}_{j}^{T} \boldsymbol{\theta}_{i}+d_{j}\right)}{1+\exp \left(\boldsymbol{a}_{j}^{T} \boldsymbol{\theta}_{i}+d_{j}\right)}
$$

上式で $x_{i j}$ は項目 $j$ について受検者 $i$ が正解した場合 に 1 , 誤答の場合に 0 をとる 2 值の回答データである. また $\boldsymbol{a}_{j}$ は項目 $j$ の各次元の識別力を縦に並べたべク トル， $d_{j}$ は項目 $j$ の困難度に関連するパラメータ, $\boldsymbol{\theta}_{i}$ は受検者 $i$ の各次元の能力特性值を縦に並べた能力特 性值を表すべクトルである.

いま (1) 式の指数関数の中の部分を取り出して $z=$ $\boldsymbol{a}_{j}^{T} \boldsymbol{\theta}_{i}+d_{j}$ とし, これをテストを構成する項目および 受検者についてまとめた次の行列について考える.

2) ただし，本研究で提案する等化法の適用可能範囲は 2 パラメータ・ロジスティック補償型モデルに限定され るものではなく, 3 パラメータ・モデル, 正規累積モ デルなど多くの補償型のモデルに適用可能である. 


$$
Z=\Theta A^{T}+\mathbf{1}_{n} \boldsymbol{d}^{T}
$$

ただし，上式右辺の $\Theta$ は $\boldsymbol{\theta}_{i}^{T}$ を受検者数分縦に並べた $n \times m$ の行列, $A$ は $\boldsymbol{a}_{j}^{T}$ を項目数分縦に並べた $p \times m$ の行列， $\mathbf{1}_{n}$ は 1 を $n$ 個縦に並べた縦ベクトル， $\boldsymbol{d}$ は $d_{j}$ を項目数分縦に並べた要素数が $p$ の縦べクトルであ る. なお, $m$ は次元の数, $p$ はテス卜を構成する項目 の数, $n$ は受検者数をそれぞれ表す.

ここで，(2) 式の $\Theta, A, \boldsymbol{d}$ について，任意の正則な $m \times m$ の行列 $W$ と要素数が $m$ のベクトル $\boldsymbol{u}$ を利用 して，それぞれ次のように変換することを考える.

$$
\begin{aligned}
& \tilde{\Theta}=\Theta W+\mathbf{1}_{n} \boldsymbol{u}^{T}, \\
& \tilde{A}^{T}=W^{-1} A^{T}, \\
& \tilde{\boldsymbol{d}}=\boldsymbol{d}-A\left(W^{-1}\right)^{T} \boldsymbol{u} .
\end{aligned}
$$

このとき，(2) 式の $\Theta, A, \boldsymbol{d}$ をそれぞれ $\tilde{\Theta}, \tilde{A}, \tilde{\boldsymbol{d}}$ と入 れ替えても

$$
\begin{aligned}
& \tilde{Z}=\tilde{\Theta} \tilde{A}^{T}+\mathbf{1}_{n} \tilde{\boldsymbol{d}}^{T} \\
& =\left(\Theta W+\mathbf{1}_{n} \boldsymbol{u}^{T}\right) W^{-1} A^{T}+\mathbf{1}_{n}\left[\boldsymbol{d}-A\left(W^{-1}\right)^{T} \boldsymbol{u}\right]^{T} \\
& =\Theta A^{T}+\mathbf{1}_{n} \boldsymbol{d}^{T}
\end{aligned}
$$

となって (2) 式に一致する。すなわち, 2 パラメー夕 . ロジスティック補償型モデルの多次元 IRT では能力特 性值 $\boldsymbol{\theta}$ と項目パラメータ $A, \boldsymbol{d}$ の間に一種の不定性が 存在し, 能力特性值と項目パラメータの双方に上記の ような変換を行なっても正答確率には影響を与えない ことがわかる。

\section{3. 共通受検者による等化}

前述の不定性を利用することで, 多次元 IRT の等化 を行うことができる，等化の方法には共通項目による 方法と共通受検者による方法がある (Reckase, 2009) が，ここでは共通受検者による等化について考える. 同じ能力次元を測定する 2 つのテスト・フォーム ${ }^{3)}$ ついて, 両方に共通する受検者が存在し, 各受検者の 能力特性值がテスト・フォームを通じて変わらないこ とを仮定できる場合には，共通受検者のデー夕を利用 して 2 つのテストを等化することができる.

等化先のテストにおける $n$ 人分の受検者の能力特性

3) 例えば英語のテストの場合, 文法的知識と単語に関す る知識の 2 つを同時に測定するためのテストが $2 つ$ 存在するような場合
值の行列を $\Theta$, 等化対象となるテストにおける同じ受 検者群の能力特性值の行列を $\Theta_{g}$ と記すことにする. なお $\Theta_{g}$ の行および列は $\Theta$ とそれぞれ対応しているも のとし, $\Theta$ と $\Theta_{g}$ の関係に次式を仮定する.

$$
\Theta=\Theta_{g} W_{g}+\mathbf{1}_{n} \boldsymbol{u}_{g}^{T}
$$

上式の $\boldsymbol{u}_{g}$ は $\Theta_{g}$ の位置の変換に対応するべクトル， $W_{g}$ は回転 (rotation), 伸縮 (dilation) の変換を表す 行列である. 以降簡単のために, $\Theta$ と $\Theta_{g}$ は共に各列 の平均が 0 , 分散が 1 に標準化されているものとする.

$$
\begin{aligned}
& \overline{\boldsymbol{\theta}}=\overline{\boldsymbol{\theta}}_{g}=0, \\
& \operatorname{diag}(S)=\operatorname{diag}\left(S_{g}\right)=I .
\end{aligned}
$$

このとき $\boldsymbol{u}_{g}=0$ である。ただし $\overline{\boldsymbol{\theta}}, \overline{\boldsymbol{\theta}}_{g}$ はそれぞれ $\boldsymbol{\theta}$, $\boldsymbol{\theta}_{g}$ の平均, $S, S_{g}$ はそれぞれ $\boldsymbol{\theta}$ と $\boldsymbol{\theta}_{g}$ の分散共分散行 列を表す.この場合, 等化の問題は等化後の $\boldsymbol{\theta}_{g}$ の各 次元の分散が 1 という制約条件下で $\Theta$ と $\Theta_{g}$ を一致に 近づけるような $(6)$ 式の $W_{g}$ を求めることであり, 次 のように定式化できる.

$$
\begin{array}{ll}
\min & f=\frac{1}{2} \operatorname{tr}\left[\left(\Theta-\Theta_{g} W_{g}\right)^{T}\left(\Theta-\Theta_{g} W_{g}\right)\right] \\
\text { s.t. } & \operatorname{diag}\left(W_{g}^{T} S_{g} W_{g}\right)=I .
\end{array}
$$

$W_{g}$ が得られれば (4) 式から項目パラメータである $A$ についても等化後の值を得ることができる.

ところで (2) 式の $A$ を因子負荷量行列, $\Theta$ を因子 スコア行列とした因子分析モデルと見なした場合, 多 次元 IRT に扔ける等化の問題は因子分析に扔ける回転 の問題として捉えることができる. 本研究では (8) 式 の制約下で (7) の問題の解を得る方法として, 斜交プ ロクラステス回転による方法, Hirsch の方法 (Hirsch, 1989), 重み付き直交プロクラステス回転による方法の 3 つについて検討する。 このうち Hirsch の方法は, 先 行研究によって示されたものであり, 他の 2 つの方法 は因子分析における因子負荷量に注目した回転法を多 次元 IRT の等化に応用したものである。な拉, 通常因 子分析では因子負荷量に注目して回転の問題が取り扱 われるが，本研究で検討する共通受検者による等化は 因子スコアに注目した回転に対応している。したがっ て, 斜交プロクラステス回転と重み付きプロクラステ ス回転については, 因子スコアに注目した回転の場合の 解が必要となる，以下で，これらの解についても示す. 


\section{1. 斜交プロクラステス回転による方法（OQ）}

$W_{g}$ を斜交回転行列であると考え，(8) 式の制約を考 慮せずに $(7)$ 式を最小化する $W_{g}$ を求めると

$$
W_{g}=\frac{1}{n} S_{g}^{-1} \Theta_{g}^{T} \Theta
$$

となる．このとき， $\boldsymbol{\theta}_{g}$ の変換後の分散共分散行列は，

$$
\begin{aligned}
& W_{g}^{T} S_{g} W_{g}=\left(\frac{1}{n} S_{g}^{-1} \Theta_{g}^{T} \Theta\right)^{T} S_{g}\left(\frac{1}{n} S_{g}^{-1} \Theta_{g}^{T} \Theta\right) \\
& =\frac{1}{n^{2}} \Theta^{T} \Theta_{g} S_{g}^{-1} \Theta_{g}^{T} \Theta
\end{aligned}
$$

となるが，この対角成分は必ずしも 1 にはならず (8) 式の制約は満たされない.したがって変換後の各次元 の分散が 1 となるよう次の調整を行う.

$$
W_{g}^{*}=W_{g}\left[\operatorname{diag}\left(W_{g}^{T} S_{g} W_{g}\right)\right]^{-1 / 2} .
$$

因子分析における因子負荷量に注目した回転の場合, 調整後の回転行列 $W_{g}^{*}$ は一種の近似解であり, 制約条 件下で目的関数を厳密に最小化するものとはならない (市川, 2010) が, 本研究で取り扱う能力特性值すなわ ち因子スコアに注目した回転の場合には，この方法で厳 密な解が得られる。詳細な導出については付録に記す.

\subsection{Hirsch の方法（HM）}

Hirsch (1989) は, 次の方法で $W_{g}$ を求めることを 提案している.

まず $\Theta$ と $\Theta_{g}$ の基底を揃えるために $\Theta_{g}$ を

$$
\Theta_{g}^{*}=\Theta_{g} P \Lambda^{-1 / 2} \Delta^{1 / 2} Q^{T}
$$

と変換する。ただし $\Lambda, P$ はそれぞれ $S_{g}$ をスペクトル 分解した場合の固有值を対角に並べた行列と, 対応する 固有べクトルを順に並べた行列, $\Delta, Q$ は $S$ をスペクト ル分解した場合の固有值を対角に並べた行列と固有べク トルを順に並べた行列で, $S_{g}=P \Lambda P^{T}, S=Q \Delta Q^{T}$, $P P^{T}=P^{T} P=Q^{T} Q=Q Q^{T}=I$ である.

つぎに, 変換後の $\Theta_{g}^{*} に \Theta$ をターゲットとした直交 プロクラステス回転 (付録参照)を適用することによっ て回転行列 $T$ を求める. $T$ が得られれば $W_{g}$ は,

$$
W_{g}=P \Lambda^{-1 / 2} \Delta^{1 / 2} Q^{T} T
$$

によって求めることができる．このとき変換後の $\boldsymbol{\theta}_{g}$ の 分散共分散行列は

$$
W_{g}^{T} S_{g} W_{g}
$$

$$
\begin{aligned}
& =\left(P \Lambda^{-1 / 2} \Delta^{1 / 2} Q^{T} T\right)^{T} S_{g}\left(P \Lambda^{-1 / 2} \Delta^{1 / 2} Q^{T} T\right) \\
& =T^{T} S T
\end{aligned}
$$

となる。もし $S=I$ であれば上式は $T^{T} S T=I$ とな

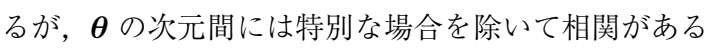
ため，一般には $S=I$ ではない.したがって Hirsch の方法によって等化を行った場合の変換後の能力特性 值の分散共分散行列は, 通常等化先の能力特性值のも のとは一致しない.

\section{3. 重み付きプロクラステス回転による方法 (WP)}

Hirsch の方法では, $\Theta$ と $\Theta_{g}$ の基底を一致させてか ら回転を行なっているが, 別の方法として基底の変換 と直交回転を同時に実現することが考えられる ${ }^{4}$. こ の場合，等化は次の基準を最小化する直交回転行列 $T$ を求めることに対応する.この方法では, 後述するよ うに変換後の $\boldsymbol{\theta}_{g}$ の分散共分散行列が $\boldsymbol{\theta}$ の分散共分散 行列に必ず一致する。

$$
\begin{gathered}
f=\frac{1}{2} \operatorname{tr}\left[\left(\Theta-\Theta_{g} W_{g}\right)^{T}\left(\Theta-\Theta_{g} W_{g}\right)\right] \\
=\frac{1}{2} \operatorname{tr}\left[\left(\Theta-\Theta_{g} P \Lambda^{-1 / 2} T \Delta^{1 / 2} Q^{T}\right)^{T}\right. \\
\left.\left(\Theta-\Theta_{g} P \Lambda^{-1 / 2} T \Delta^{1 / 2} Q^{T}\right)\right] .
\end{gathered}
$$

ところで (10) 式は

$$
\begin{aligned}
f= & \frac{1}{2} \operatorname{tr}\left[\left(\Theta Q \Delta^{-1 / 2}-\Theta_{g} P \Lambda^{-1 / 2} T\right)\left(\Delta^{1 / 2} Q^{T}\right)\right. \\
& \left.\left(Q \Delta^{1 / 2}\right)\left(\Theta Q \Delta^{-1 / 2}-\Theta_{g} P \Lambda^{-1 / 2} T\right)^{T}\right] \\
= & \frac{1}{2} \operatorname{tr}\left[\left(\Theta_{L}-\Theta_{g L} T\right) \Delta\left(\Theta_{L}-\Theta_{g L} T\right)^{T}\right]
\end{aligned}
$$

と変形することができる。ただし $\Theta_{L}=\Theta Q \Delta^{-1 / 2}$, $\Theta_{g L}=\Theta_{g} P \Lambda^{-1 / 2}$ とした。 ここで $\Theta_{L}, \Theta_{g L}$ は, そ れぞれ $\Theta$ と $\Theta_{g}$ を直交化した行列であると見なせるか ら，上式の基準を最小化する $T$ は， $\Theta$ と $\Theta_{g}$ をそれぞ れ直交化した後に， $\Delta$ を重みとして考慮した重み付き プロクラステス回転 (Koschat \& Swayne, 1991) とな る. $T$ が得られれば $W_{g}$ は,

$$
W_{g}=P \Lambda^{-1 / 2} T \Delta^{1 / 2} Q^{T}
$$

4) 柳井・前川・繁柲・市川 (1990)の p.22 および p.97 を参考にした。なお，この方法ではHirsch の方法と 同様, 途中の展開において直交回転を利用するが, 全 体としては斜交回転となる. 
によって求めることができる.この場合の等化後の $\boldsymbol{\theta}_{g}$ の分散共分散行列は

$$
\begin{aligned}
& W_{g}^{T} S_{g} W_{g}=W_{g}^{T} P \Lambda P^{T} V_{g} \\
& =\left(P \Lambda^{-1 / 2} T \Delta^{1 / 2} Q^{T}\right)^{T}\left(P \Lambda P^{T}\right)\left(P \Lambda^{-1 / 2} T \Delta^{1 / 2} Q^{T}\right) \\
& =Q \Delta Q^{T}=S
\end{aligned}
$$

となって等化先の $\boldsymbol{\theta}$ のものと常に一致する.

さて (10) 式を展開すると,

$$
\begin{gathered}
f=\frac{1}{2}\left[\operatorname{tr}\left(\Theta_{L}^{T} \Delta \Theta_{L}\right)-2 \operatorname{tr}\left(\Delta \Theta_{L}^{T} \Theta_{g L} T\right)\right. \\
\left.+\operatorname{tr}\left(\Theta_{g L} T \Delta T^{T} \Theta_{g L}^{T}\right)\right]
\end{gathered}
$$

となるが，上式の右辺括弧内の第 1 項は $\Theta$ が所与の場 合には定数と見なすことができる．また，右辺第 3 項 についても $\operatorname{tr}\left(\Theta_{g L} T \Delta T^{T} \Theta_{g L}^{T}\right)=\operatorname{tr} \Delta=\operatorname{tr} S$ となる から，やはり定数と見なすことができる．したがって， この場合の $f$ を最小化する $T$ は, $\operatorname{tr}\left(\Delta \Theta_{L}^{T} \Theta_{g L}\right) T$ を 最大化するような $T$ であり, 因子スコアに注目した直 交プロクラステス回転（付録参照）を利用して

$$
T=\Theta_{g L}^{T} \Theta_{L} \Delta\left(\Delta \Theta_{L}^{T} \Theta_{g L} \Theta_{g L}^{T} \Theta_{L} \Delta\right)^{-1 / 2}
$$

と解析的に求めることができる.

\section{4. 実験 1 ：能力特性值の相関に関する実験}

これら 3 つの等化法について，それぞれの性質を確 認するために計算機を用いたシミュレーション実験を 行った。実験の手順は以下のとおりである.

まず, $N=300$ 人の仮想的な受検者の $m=2$ 次元 の能力特性値 $\boldsymbol{\theta}_{i}(i=1,2, \ldots, N)$ と $p=40$ 個の問題 項目の項目パラメータ $\boldsymbol{a}_{j}$ および $d_{j}(j=1,2, \ldots, p)$ を, $\boldsymbol{\theta}_{i}$ については, $\boldsymbol{\theta}_{i} \sim N\left(\left[\begin{array}{l}0 \\ 0\end{array}\right],\left[\begin{array}{ll}1 & \rho \\ \rho & 1\end{array}\right]\right), \boldsymbol{a}_{j}$ と $d_{j}$ は $\boldsymbol{a}_{j} \sim N\left(\mathbf{0}, \sigma_{a}^{2} I\right), \sigma_{a}^{2}=0.5^{2}, d_{j} \sim N(0,1)$ としてそ れぞれ乱数で生成した。 なお，能力特性の次元間の相 関の強さによる影響を考慮して，相関係数 $\rho$ について は $0.1,0.3,0.5,0.7,0.9$ の 5 パターンを用意した.

つぎに $\boldsymbol{\theta}_{i}$ と $\boldsymbol{a}_{j}, d_{j}$ を(1) 式のモデルに代入して正 答確率を求め, 一様乱数によってそれぞれの受検者の 問題項目に対する 2 值の正誤デー夕 $(0,1)$ を生成した. 生成した正誤データについて項目パラメータおよび受 検者の能力特性值 $\boldsymbol{\theta}_{g i}$ の推定を行った.

このようにして推定した受検者毎の能力特性值を転 置した $\boldsymbol{\theta}_{g i}^{T}$ を受検者数分縦に並べた行列 $\Theta_{g}$ について,
真の能力特性值を転置した $\boldsymbol{\theta}_{i}^{T}$ を受検者数分縦に並べ た行列 $\Theta$ を等化先として等化を行った。等化の方法と しては，前述の 3 つの方法に直交プロクラステス回転 （付録参照）を加えた計 4 つの方法を用いた。

上記の手続きを相関係数 $\rho$ の各值について, そ れぞれ $\mathrm{c}=200$ 回繰り返し,つぎに示す $R M S E(\boldsymbol{\theta})$, $R M S E(r), R M S E(A)$ の值を求めた.

$$
R M S E(\boldsymbol{\theta})=\sqrt{\frac{1}{c m N} \sum_{k=1}^{c} \sum_{i=1}^{N}\left\|W_{g}^{T} \boldsymbol{\theta}_{g i}-\boldsymbol{\theta}_{i}\right\|_{k}^{2}}
$$

$R M S E(\boldsymbol{\theta})$ は, 值が小さいほど等化後の $\boldsymbol{\theta}_{g}$ と等化先 の $\boldsymbol{\theta}$ が一致傾向にあることを表す。

また, $R M S E(r)$ は, 等化後の $\boldsymbol{\theta}_{g}$ の次元間の相関 係数に関連する指標で, 值が小さいほど等化後の $\theta_{g}$ の 次元間の相関係数が等化先の $\boldsymbol{\theta}$ の次元間の相関係数に 平均的に近いことを表している.

$$
R M S E(r)=\sqrt{\frac{1}{c} \sum_{k=1}^{c}\left[r\left(W_{g}^{T} \boldsymbol{\theta}_{g}\right)-r(\boldsymbol{\theta})\right]_{k}^{2}} .
$$

上式の $r\left(W_{g}^{T} \boldsymbol{\theta}_{g}\right)$ は等化後の $\boldsymbol{\theta}_{g}$ の次元間の相関係数, $r(\boldsymbol{\theta})$ は等化先の $\boldsymbol{\theta}$ の次元間の相関係数である.

$R M S E(A)$ は，等化後の項目パラメー夕 $A$ に関連 する指標で，值が小さいほど等化後の $A$ パラメータが 等化先の $A$ に近いことを表す.

$$
\operatorname{RMSE}(A)=\sqrt{\frac{1}{c m p} \sum_{k=1}^{c}\left\|W_{g}^{-1} A_{g}^{T}-A^{T}\right\|_{k}^{2}}
$$

上式の $W_{g}^{-1} A_{g}^{T}$ は等化後の $A$ パラメー夕行列, $A^{T}$ は 等化先の $A$ パラメータ行列である.

なお， シミュレーション実験のプログラムは R3.0.0 (R Development Core Team, 2013) によって作成し た. また, 多次元 IRT の項目パラメータと受検者の能 カパラメータの推定には mirt パッケージ (Chalmers, 2012)を利用した。

$R M S E(\boldsymbol{\theta})$ に関する結果を図 1 に, RMSE $(r)$ に 関する結果を図 2 に, RMSE $(A)$ に関する結果を表 1 にそれぞれまとめる。

まず, $R M S E(\boldsymbol{\theta})$ についてみると, 全般に次元間の 相関係数が小さい場合には各手法間の差が小さいが, 次元間の相関が大きくなるに従って等化法間の差が大 きくなっていることがわかる．今回検討する等化法は， 能力特性値間の相関をどのように捉えるかという点に 


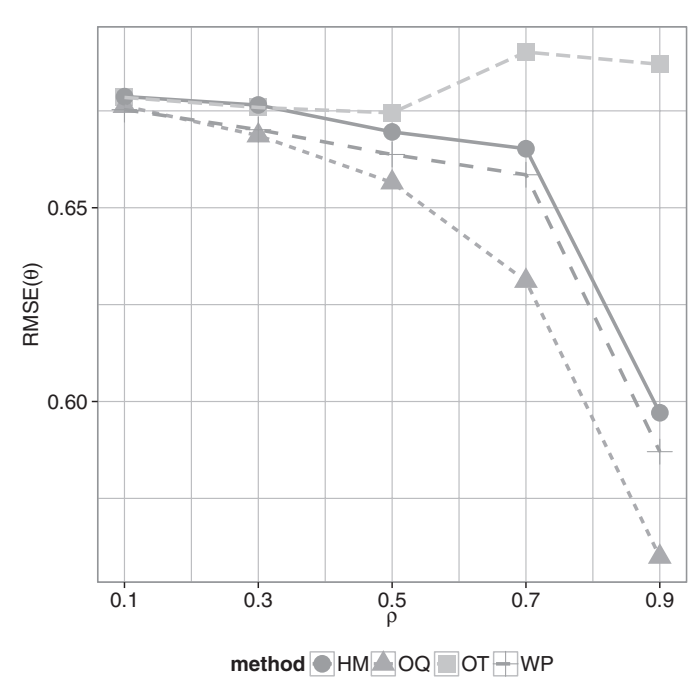

図 1. シミュレーション結果 $\operatorname{RMSE}(\theta)$

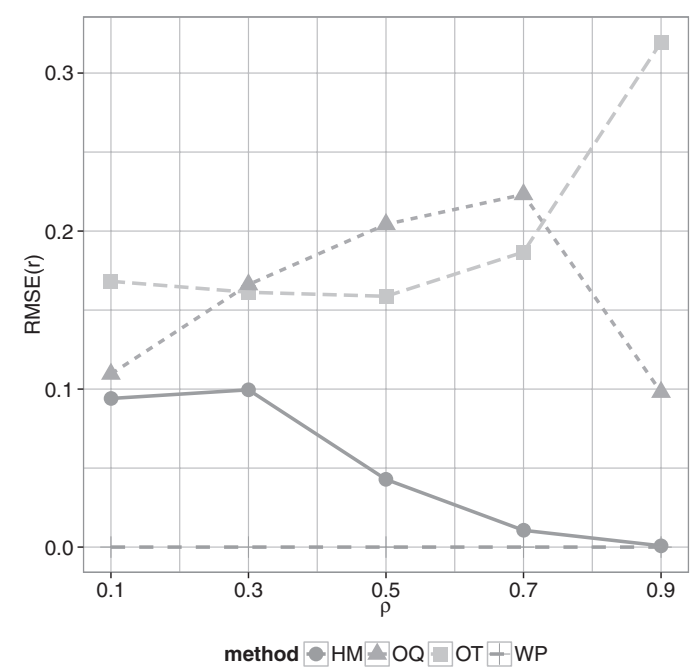

図 2. シミュレーション結果 $R M S E(r)$

違いがあるため，相関が大きいほど差異が明確になる のは妥当な結果であると言える。

以下では, $R M S E(\rho), R M S E(A)$ の結果も含めて, 4 つの等化法に関する結果を順にみていくと，まず直交 プロクラステス回転法 $(\mathrm{OT})$ では, 特に $\rho$ の值が大き く次元間に相関がある場合に, $R M S E(\boldsymbol{\theta}), R M S E(r)$ の值が双方とも大きくなっている。これは，因子スコ アによる直交プロクラステス回転が，能力特性值の次 元間に直交性を仮定しており，能力特性值の相関に上
表 1. $\rho$ 毎の $R M S E(A)$

\begin{tabular}{ccccc}
\hline & OT & OQ & HM & WP \\
\hline \hline$\rho=0.1$ & .73 & .73 & .73 & .73 \\
& $(.21)$ & $(.21)$ & $(.21)$ & $(.21)$ \\
\hline$\rho=0.3$ & .72 & .73 & .71 & .72 \\
& $(.21)$ & $(.21)$ & $(.21)$ & $(.21)$ \\
\hline$\rho=0.5$ & .74 & .78 & .74 & .74 \\
& $(.20)$ & $(.21)$ & $(.20)$ & $(.20)$ \\
\hline$\rho=0.7$ & .77 & 14.14 & .79 & .79 \\
& $(.21)$ & $(13.95)$ & $(.20)$ & $(.21)$ \\
\hline$\rho=0.9$ & .78 & 81.79 & .96 & .96 \\
& $(.21)$ & $(79.22)$ & $(.26)$ & $(.27)$ \\
\hline
\end{tabular}

※括弧内の数值は各繰り返し毎の $\operatorname{RMSE}(\mathrm{A})$ の標準偏差

手く追従できないためであると考えられる。ただし， OT 法で $\rho$ の值が 0.9 と大きい場合に $R M S E(A)$ の 值が他の手法に比べて小さくなっている. OT 法は, 能 力特性值を等化先に近づけすぎない分, 項目特性值の 側から見ると安定した結果が得られている可能性もあ る.これは, 特に多次元 IRT の等化において, 等化対 象のテストと等化先のテストで受検者の能力特性值を 近接させることが，必ずしも項目特性值を近接させる ことを同時に実現するものではないことを示す点で注 目すべき結果であると言える。

つぎに，斜交プロクラステス回転法 $(\mathrm{OQ})$ について みると, いずれの $\rho$ の值についても $R M S E(\boldsymbol{\theta})$ が他 の手法に対して小さな值となっていた。これは，斜交 プロクラステス回転法が最も少ない制約の下で等化先 と等化後の能力特性值を近接させる構造となっている ことの結果であると思われる，ただし， $\rho$ の值が大き い場合に RMSE $(r)$ の值が比較的大きくなっており, 相関構造の再現性という点でみると斜交プロクラステ ス回転は必ずしも優れた方法とはいえない点に注意が 必要である. 能力特性值の次元間の相関関係はテスト が測定する次元間の関係性に対応するものと考えられ るが，等化によってこれが大きく変化してしまうこと はテストの運用という面では望ましい性質ではない.

ところで $\rho$ が大きい場合の斜交プロクラステス回転 による等化後の $\boldsymbol{\theta}_{g}$ の次元間相関を確認したところ, 值 が 1 に近いケースが見られた（図 3)。これは一部に は実験において $\boldsymbol{a}$ パラメータを小さく設定したことの 結果であるが，斜交プロクラステス回転を利用した等 化では等化後の能力特性值の次元が縮退してしまう可 


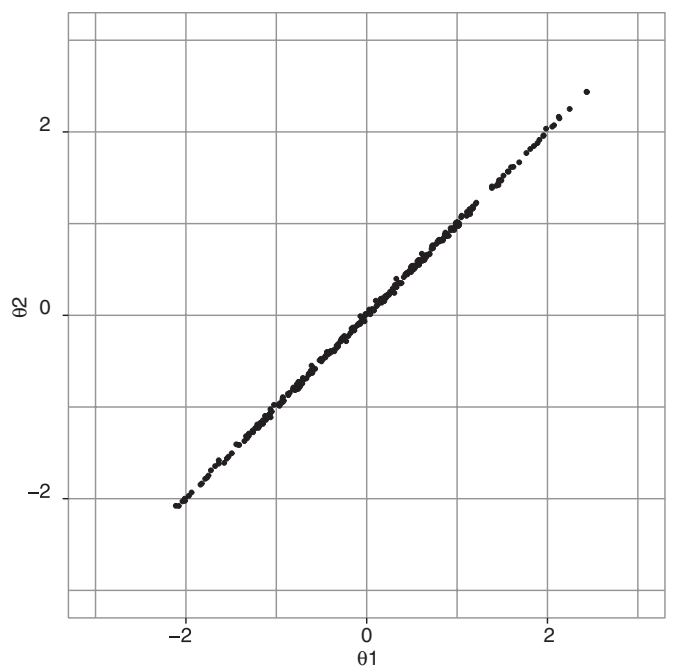

図 3. $\mathrm{OQ}$ 法による等化後の $\theta$ の例 $\rho=0.9$ の場合

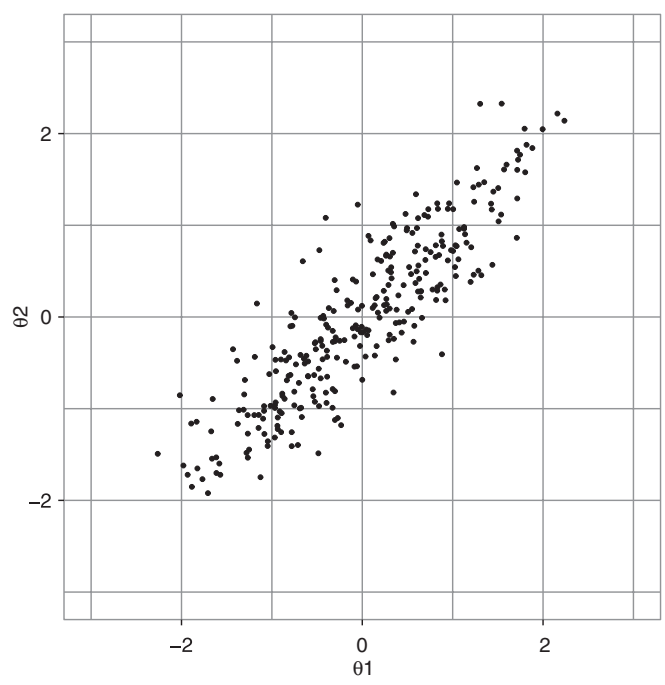

図 4. WP 法による等化後の $\theta$ の例 $\rho=0.9$ の場合

能性があることを表すものである。テストが測定内容 の面でも想定した次元数に対応しているとすれば, こ のような状況はやはり適切なものではない。なお，同 様の現象は他の等化法, 例えば重み付きプロクラステ ス回転法に拈いては見られなかった（図 4).また，項 目パラメー夕に関する指標である $R M S E(A)$ につい て見ても，斜交プロクラステス回転では次元間相関が 0.7 以上の場合に值が極めて大きくなっており, 項目
パラメータの再現についてもうまく行っていないこと がわかる．特に次元間の相関が高い場合に斜交プロク ラステス回転を利用する際には，等化後のパラメータ が妥当なものであるか十分注意する必要があると考え られる。

Hirsch の方法（HM）と重み付きプロクラステス回 転による方法 (WP) は, コンセプトに扔いて類似性 が高いため，比較する形で結果を確認する。まず図 2 において， $\rho$ の值に関わらず重み付きプロクラステス 回転による方法では $R M S E(r)$ の值が常にゼロになっ ていることがわかる。これは (11) 式で示したように， この手法では等化後の能力特性值の次元間の相関が等 化先の能力特性值の次元間の相関に常に一致すること の結果である。一方の Hirsch の方法では特に $\rho$ の值 が小さい場合に $R M S E(r)$ が比較的大きな值となって いる. また, 図 1 の $R M S E(\boldsymbol{\theta})$ の結果を見ると, $\rho$ の 值にかかわらず重み付きプロクラステス回転法のほう が值が小さくなっており, 等化後の $\boldsymbol{\theta}_{g}$ と等化先の $\boldsymbol{\theta}$ の近接性という面でも重み付きプロクラステス法のほ うが優れていることがわかる. したがって, 共通受検 者による等化において次元間の相関の再現性が求めら れる場合には, Hirschの方法よりも重み付きプロクラ ステス回転による方法を利用するほうが，一般に良好 な結果が得られるものといえる.

これらの結果から, 能力特性值間の相関が 0.3 を目 安として一定の水準を超えるような場合の共通受検者 による等化法としては, 重み付きプロクラステス回転 による方法（WP）を利用することが適切だと考えら れる。一方，特に等化対象のテストと等化先のテスト で能力特性值を一致させる要請が強い場合には, 斜交 プロクラステス回転法 $(\mathrm{OQ})$ の利用が検討されてもよ い.ただし，この場合には能力特性値間の相関構造は 再現されないこと, 能力特性值間の相関が強い場合に は項目パラメータや能力特性值そのものが不安定にな ることに注意する必要がある。

\section{5. 実験 $2 ：$ 項目数に関する実験}

つぎに, 問題項目数を变化させた場合の各等化法の違 いを確認するために, 能力特性值間の相関係数は $\rho=0.7$ に固定し, 項目数 $p$ について 20,40，100，200の 4 パターンを用意して実験を行った. 相関係数と項目数 以外の設定および評価の指標は実験 1 と同様である. $R M S E(\boldsymbol{\theta})$ に関する結果を図 3 に $R M S E(r)$ に関す 


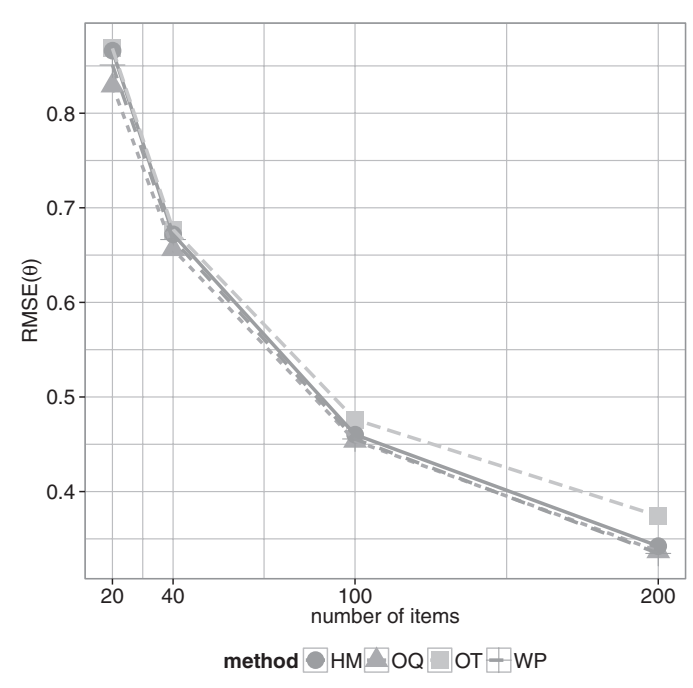

図 5. シミュレーション結果 $\operatorname{RMSE}(\theta)$

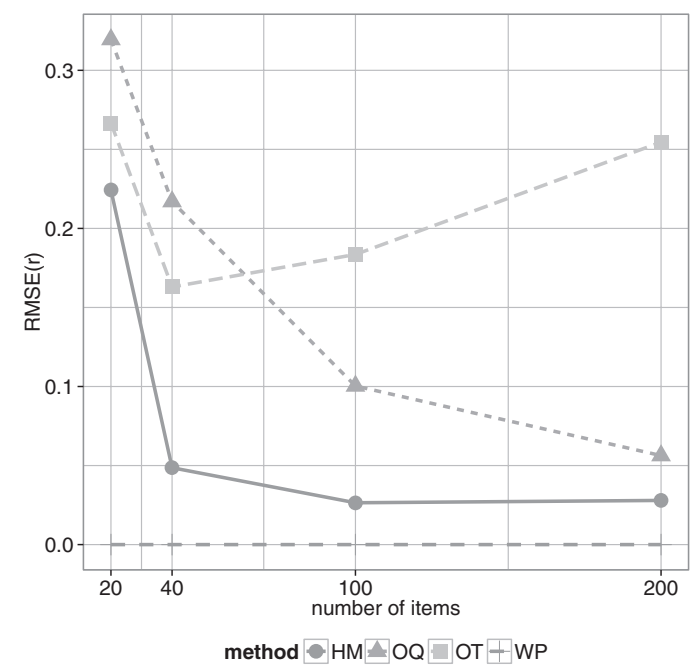

図 6. シミュレーション結果 $R M S E(r)$

る結果を図 4 に, RMSE $(A)$ に関する結果を表 2 に それぞれまとめる。

まず, $R M S E(\boldsymbol{\theta})$ の結果をみると, 項目数が増える ほどどの手法でも明らかに值が小さくなる傾向がある ことがわかる，これは，項目数を増やすことで等化前 の能力特性值の推定精度が高くなることの効果である と考えられる。 また, $R M S E(\boldsymbol{\theta})$ の值は, 項目数に関 わらず OQ 法, WP 法, HM 法, OT 法の順に小さく なっており，等化対象のテストと等化先のテストの能
表 2. 項目数毎の $R M S E(A)$

\begin{tabular}{lcccc}
\hline 項目数 & OT & OQ & HM & WP \\
\hline \hline$p=20$ & .77 & 2.24 & .77 & .81 \\
& $(.26)$ & $(1.85)$ & $(.26)$ & $(.30)$ \\
\hline$p=40$ & .76 & .85 & .77 & .77 \\
& $(.21)$ & $(.28)$ & $(.21)$ & $(.21)$ \\
\hline$p=100$ & .84 & .88 & .85 & .85 \\
& $(.25)$ & $(.25)$ & $(.25)$ & $(.25)$ \\
\hline$p=200$ & .90 & .93 & .92 & .92 \\
& $(.27)$ & $(.27)$ & $(.27)$ & $(.27)$ \\
\hline
\end{tabular}

※括弧内の数值は各繰り返し毎の $\operatorname{RMSE}(\mathrm{A})$ の標準偏差

力特性值の一致度合という観点でみると，この順で有 効な方法であると考えられる。

$R M S E(\rho), R M S E(A)$ の結果も含めて 4 つの等化 法に関する結果を順にみていくと, 直交プロクラステス 回転法 $(\mathrm{OT})$ では $R M S R(\boldsymbol{\theta}), R M S R(r)$ の両指標と もに他の等化法と比較して相対的に大きな值となって おり, 特に項目数が多い場合にこの傾向が顕著であるこ とがわかる，OT法は今回検討する 4 つの手法の中で最 も制約の強い方法であり, 能力特性值の近接度, 相関構 造の再現性の面では他の手法のほうが有利であると言 える. $R M S R(\boldsymbol{\theta}), R M S R(r)$ の值が大きくなるのは, このことを反映したものである．ただし $R M S E(A)$ をみると, いずれの項目数の場合についても他の手法 よりも值が小さくなっており, 相関係数の実験結果と 併せて考えると, 特に次元間の相関が強い場合には, 項 目特性值については直交プロクラステス回転法が安定 した結果をもたらすものと考えられる。

斜交プロクラステス回転法 (OQ) は, $R M S R(\boldsymbol{\theta})$ が 項目数に関わらず 4 つの等化法の中で最も小さい值と なっており, 等化対象のテストと等化先のテストの能 力特性值を一致に近づけるという点で優れた方法であ るといえる. 前述の項目数を 40 に固定した相関係数に 関する実験では, 能力特性值の次元間の相関が高い場 合に相関構造や項目パラメータの再現性において問題 が見られた。一方, 項目数に関する結果をみると, 項 目数が多くなるほど $R M S E(r), R M S E(A)$ の值は改 善し, 特に項目数が 80 問を超えると $R M S E(A)$ の值 は他の等化法と遜色ない值となっている。これらの結 果から, 相関構造の再現性があまり重要ではなく能力 特性值の近接性が重視される場合で, かつテストを構 成する項目数が十分多いような状況では, 斜交プロク 
ラステス回転は有効な方法であると考えられる.

Hirsch の方法 (HM) と重み付きプロクラステス回転 による方法 (WP) をみると, $R M S R(\boldsymbol{\theta}), R M S R(r)$, $R M S R(A)$ の各值とも, 項目数が多くなるにしたがっ て両手法での差は小さくなっており, 特に項目数が 80 以上の場合にはかなり近接した結果となっていること がわかる。ここから，Hirsch の方法と重み付きプロク ラステス回転による方法は, 特に項目数が多い場合に は類似した特徵を示すものと考えられる。ただし，重 み付きプロクラステス回転による方法では $R M S R(r)$ の值が常にゼロとなることを考慮すれば，やはり重み 付きプロクラステス回転法のほうが実用上は有利であ るものと思わ妃る。

\section{6. まとめと課題}

複数のテストのスコアを比較可能なものとする等化 法に関する研究は, IRT において重要な課題である. これは多次元 IRT においても同様であるが，特に共通 受検者による多次元 IRT の等化法に関する研究はこれ まであまりなされてこなかった。

本研究では, 多次元 IRT における共通受検者を利用 した場合の等化について, 先行研究で示された Hirsch の方法に加えて，因子分析に扔ける回転法を応用した 斜交プロクラステス回転法, 重み付きプロクラステス 回転法の 2 つの方法を示し, これに直交プロクラステ ス回転法を加えた 4 つの方法について計算機によるシ ミュレーション実験を行って性質を検証した。なお， 通常の因子分析では，因子負荷量に注目した回転が利 用されるが，共通受検者による等化は因子スコアに注 目した回転に相当する。このため，因子スコアに注目 した斜交プロクラステス回転および重み付きプロクラ ステス回転の解を示した。

実験の結果，等化後の個人の能力特性值と等化先の 個人の能力特性值を一致に近づけることを第一に考え る場合には，斜交プロクラステス回転法が最も有効な 手法であることが示された。ただし，テストを構成す る項目数が少ない場合に, 斜交プロクラステス回転法 では等化後の能力特性值の次元間の相関係数が等化先 のそれを再現したものとならないことがあることがわ かった．能力特性間の次元間の相関は，テストが測定 している能力特性間の関係性を表すものであるが，斜 交プロクラステス回転を利用した等化では，この関係が 変化してしまう可能性がある点には注意が必要である。
また, 等化後の能力特性值の次元間の相関を等化先 に一致させることが重視される場合には，重み付きプ ロクラステス回転による方法が有効であることが確認 できた，重み付きプロクラステス回転では，等化後の 能力特性值についても斜交プロクラステス回転法に次 いで等化先の能力特性值との近接性が高い結果となっ ており，特に能力特性值の次元間の相関が小さい場合 には斜交プロクラステス回転法との差が小さい傾向で あった、したがって, 等化にあたって能力特性值の次 元間の相関を等化先と近づけることにも配慮する必要 がある場合，重み付きプロクラステス回転による方法 の総合的な有用性は高いものと考えられる.

ところで, 本研究では共通受検者による等化に限定 してその性質を比較したが, 多次元 IRT において共通 項目による等化と共通受検者による等化の両方が実行 できるような場合に，いずれの等化法を利用したほう が精度において望ましいかといった事柄についても， 今後把握する必要のあるテーマであると思われる。た だし，本研究で示した共通受検者による等化法では，い ずれの方法についても等化のための変換係数行列を数 值的な繰り返し計算によらず解析的に求めることがで きる。一方, 共通項目による等化では繰り返し計算が 必要となるものが多い (e.g. Simon, 2008). プログラ ム開発の負荷など実際場面での活用を考えれば，比較 的シンプルな形で等化後のパラメータが得られるとい う意味に拈いても，共通受検者による等化には利点が あるものと思われる。

さて, 本研究では等化法の特徵を把握するための指 標として, 主に能力特性値と相関係数の残差平方和に 関連する值を利用した。これらの指標は各等化法の平 均的な性質を表すものであるが, 状況によっては各手 法の平均的な特性の優劣よりもたとえば結果の安定性 のほうが重要であるケースも考えられる。この点を含 めて, 実際の状況に即したより幅広い観点から各等化 法の特徵を見極めていく必要があると言える.

また, 実験では受検者の能力特性值を二次元に設定 したが，実際のテストの運用場面では，ょり多くの次 元を考慮すべき場合もあり得る。また，受験者数につ いても特定のパターンに限定して実験を行ったが次元 数や受験者数が大きい場合を含めた，より多様な条件 においても一貫した結果が得られるかどうかについて は今後確認していく必要がある。 


\section{参 考 文 献}

Ackerman, T.A. \& Gierl, M.J., \& Walker, C.M. (2005). Using multidimensional item response theory to evaluate educational and psychological tests. Educational Measurement: Issues and Practice. 22, 3, 37-51.

Arai, S., \& Mayekawa, S. (2011). A comparison of equating methods and linking designs for developing an item pool under item response theory. Behaviormetrika, 38, 1-16.

荒井清佳 · 菊池賢一 ·前川眞一 (2013). 三つ以上のテスト フォームを等化する場合の等化精度の違いについて． 日本テスト学会第 11 回大会発表論文抄録集, 60-61.

Brown, A., \& Maydeu-Olivares, A. (2010). Item response modeling of paired comparison and ranking data. Multivariate Behavioral Research, 45, 6, 935-974.

Brown, A., \& Maydeu-Olivares, A. (2012). How IRT can solve problems of ipsative data in forcedchoice questionnaires. American Psychological Association.

Chalmers, R.P. (2012). mirt: A multidimensional item response theory package for the $\mathrm{R}$ environment. Journal of Statistical Software, 48, 6 .

藤森進 (1988). OR 型多次元項目反応モデルによる TPI 尺度データの分析. 教育心理学研究, 36, 96-103.

Haebara, T. (1980). Equating logistic ability scales by a weighted least squares method. Japanese Psychological Research, 22, 144-149.

Hirsch, T. (1989). Multidimensional equating. Journal of Educational Measurement. 26, 4, 337-349.

市川雅教 (2010). 因子分析行動計量の科学 7. 朝倉書店. 池田央 (2001). 項目応答理論. 現代テスト理論, 朝倉書店.

泉毅・山野井真児·山田剛史·金森保智・対馬英樹 (2012). 共通項目数が等化の精度に及ぼす影響 : 大規模学力 テストデータを用いた探索的研究. 教育実践学論集, $13,49-57$.

加藤健太郎 · 山田剛史 · 川端一光 (2014). R による項目 反応理論. オーム社.

Koschat, M.A., \& Swayne, D.F. (1991). A weighted Procrustes criterion. Psychometrika. 56, 2, 229239.

Li, Y.H., \& Lissitz, R.W. (2000). An evaluation of the accuracy of multidimensional IRT linking. Applied Psychological Measurement, 24, 115-138.

Lord, F.M. (1980). Applications of item response theory to practical testing problems. Hillsdale, NJ: Lawrence Erlbaum.

Min, K. (2007). Evaluation of linking methods for multidimensional IRT calibrations. Asia Pacific Education Review. 8, 1, 41-55.

光永悠彦・前川眞一 (2013). 多群 IRT モデルにおけるモ デル簡素化の評価一水平等化場面のシミュレーショ ンを通じて一. 行動計量学, 40, 29-42.

光永悠彦 ·御園真史・水町龍一 (2013). 共通項目デザイ ンを用いた多值型データによるテストにおける等化
方法の比較一大学 1 年次向け数学コンピテンシーテ ストのデータを用いて一. 日本テスト学会第 11 回大 会発表論文抄録集, 56-59.

村木英治 (2011). 項目反応理論. 朝倉書店.

Muraki, E., \& Carlson, J.E. (1995). Full-information factor analysis for polytomous item responses. Applied Psychological Measurement, 19, 73-90.

仁田善雄 · 前川眞一 - 柳本武美 · 前田忠彦 · 吉田素文 · 奈 良信雄・石田達樹 - 福島統・齋藤宣彦 - 福田康一郎 · 高久史麿・麻生武志 (2005). 項目反応理論を用いた 第 1 回共用試験医学系 CBT の統計解析. 医学教育, 36(1), 3-9.

岡田謙介・前川眞一 (2014). 補償型 · 非補償型を包含す る多次元項目反応理論モデル. 日本テスト学会第 12 回大会発表論文抄録集.

Oshima, T.C., Davey, T.C., \& Lee, K. (2000). Multidimensional linking; four practical approaches. Journal of Educational Measurement, 37, 357373.

R Core Team (2013). R: A language and environment for statistical computing. http://www.Rproject.org/.

Reckase, M.D. (1985). The difficulty of test items that measure more than one ability. Applied Psychological Measurement, 9, 401-412.

Reckase, M.D. (2009). Multidimensional item response theory. Springer.

Reckase, M.D., \& McKinley, R.L. (1991). The discriminating power of items that measure more than one dimension. Applied Psychological Measurement, 15, 361-373.

芝祐順 (編) (1991). 項目反応理論一基礎と応用. 東京大 学出版会.

Simon, M.K. (2008). Comparison of concurrent and separate multidimensional IRT linking of item parameters. PhD thesis, University of Minnesota.

孫媛 (1997). 多次元デー夕に対する項目反応モデル. 学術 情報センター紀要 第 9 号, 103-111.

Stocking, M.L., \& Lord, F.M. (1983). Developing a common metric in item response theory. Applied Psychological Measurement, 7, 201-210.

Takane, Y., \& Leeuv, J.D. (1987). On the relationship between item response theory and factor analysis of discretized variables. Psychometrika, 52, 3, 393-408.

豊田秀樹 (2012). 項目反応理論〔入門編〕(第 2 版). 朝 倉書店

柳井晴夫 ·前川眞一 - 繁枰算男 ·市川雅教 (1990). 因子 分析一その理論と方法一. 朝倉書店.

van der Linden, W.J., \& Hambleton, R.K. (Ed.) (1997). Handbook of modern item response theory. Springer.

Yao, L., \& Boughton, K. (2009). Multidimensional linking for tests with mixed item types. Journal of Educational Measurement. 46, 2, 177-197.

( 2015 年 3 月 17 日受付， 2015 年 9 月 8 日最終修正) 
付録 1 : 能力特性值（因子スコア）に注目した直交プ ロクラステス回転

次の問題について考える.

$$
\begin{aligned}
\min . & f=\frac{1}{2} \operatorname{tr}\left(\Theta-\Theta_{g} W\right)^{T}\left(\Theta-\Theta_{g} W\right) \\
\text { s.t. } & \operatorname{diag}\left(W^{T} S_{g} W\right)=I .
\end{aligned}
$$

いま $W$ が $W^{T} W=I$ を満たす直交回転行列であると する．上式の $f$ を展開すると，

$$
\begin{aligned}
f & =\frac{1}{2} \operatorname{tr}\left(\Theta^{T} \Theta-2 \Theta^{T} \Theta_{g} W+W^{T} \Theta_{g}^{T} \Theta_{g} W\right) \\
& =\frac{1}{2} \operatorname{tr}\left(n S-2 \Theta^{T} \Theta_{g} W+n W^{T} S_{g} W\right)
\end{aligned}
$$

となるが, $W^{T} W=I$ より $\operatorname{tr}\left(W^{T} S_{g} W\right)=\operatorname{tr}\left(S_{g}\right)$ で あるから，(12) 式の最小化は $\Theta^{T} \Theta_{g} W$ の最大化と同 值である. $\Theta^{T} \Theta_{g}$ が正則な場合, このような $W$ は

$$
W=\Theta^{T} \Theta_{g}\left(\Theta_{g}^{T} \Theta \Theta^{T} \Theta_{g}\right)^{-1 / 2}
$$

と求めることができる (e.g. 市川, 2010).ささて，この 場合の $\Theta_{g}$ の変換後の分散は $W^{T} S_{g} W$ の対角成分で あるが，この各成分の值は一般には 1 にならない。た だし特に $S_{g}=I$ の場合には $W^{T} W=I$ より

$$
W^{T} S_{g} W=W^{T} W=I
$$

となる. $S_{g} \neq I$ の場合には変換後の $\Theta_{g}$ の分散で $W$ を調整した

$$
W^{*}=W\left[\operatorname{diag}\left(W^{T} S_{g} W\right)\right]^{-1 / 2}
$$

を利用する。

付録 2：能力特性值（因子スコア）に注目した斜交プ

\section{ロクラステス回転}

いま $f$ が $W$ の関数であることを明示的に $f(W)$ と 書くことにすると，(12) 式の（13）式による条件付き 最小化問題は

$$
g=f(W)-\frac{1}{2} \operatorname{tr}\left[\left(\operatorname{diag}\left(W^{T} S_{g} W\right)-I\right) \Gamma\right]
$$

の最小化と同值であり，解は

$$
\left\{\begin{array}{l}
\frac{\partial g}{\partial W}=\frac{\partial f(W)}{\partial W}-S_{g} W \Gamma=0 \\
\frac{\partial g}{\partial \Gamma}=\operatorname{diag}\left(W^{T} S_{g} W\right)-I=0
\end{array}\right.
$$

を満たす。ただし，「はラグランジュの未定乗数を表 す対角行列である。ここで，

$$
G=\frac{\partial f(W)}{\partial W}
$$

とすると，(15) 式から

$$
G=S_{g} W \Gamma
$$

であり，上式の両辺に左から $W^{T}$ をかけると，

$$
W^{T} G=W^{T} S_{g} W \Gamma
$$

となる。ここで $\Gamma$ が対角行列であることに注意すると， 任意の $j(j=1,2, \ldots, m)$ について

$$
\left(W^{T} G\right)_{j j}=\left(W^{T} S_{g} W\right)_{j j} \Gamma_{j j}
$$

が成り立つ.ただし上式の下付きの添字 $j j$ は各行列 の $j$ 行 $j$ 列成分を表す.上の関係を考慮すると, (16) 式より

$$
\Gamma=\operatorname{diag}\left(W^{T} G\right)
$$

であることがわかる。これを $(15)$ 式の $\Gamma$ に代入すると

$$
\begin{aligned}
& \frac{\partial f(W)}{\partial W}-S_{g} W \operatorname{diag}\left(W^{T} G\right) \\
= & n S_{g} W-\Theta_{g}^{T} \Theta-S_{g} W \operatorname{diag}\left[W^{T}\left(n S_{g} W-\Theta_{g}^{T} \Theta\right)\right] \\
= & S_{g} W \operatorname{diag}\left(W^{T} \Theta_{g}^{T} \Theta\right)-\Theta_{g}^{T} \Theta
\end{aligned}
$$

(途中 (16) 式を利用した) となるから，

$$
S_{g} W \operatorname{diag}\left(W^{T} \Theta_{g}^{T} \Theta\right)-\Theta_{g}^{T} \Theta=0
$$

であり，Wに関連する項を右辺にまとめて

$$
S_{g}^{-1} \Theta_{g}^{T} \Theta=W \operatorname{diag}\left(W^{T} \Theta_{g}^{T} \Theta\right)
$$

を得る。いま，

$$
V=S_{g}^{-1} \Theta_{g}^{T} \Theta
$$

とすると, (17) 式から

$$
V=W \operatorname{diag}\left(W^{T} S_{g} V\right) .
$$

さらに, $\left[\operatorname{diag}\left(W^{T} S_{g} V\right)\right]_{j j} \neq 0,(j=1,2, \ldots, m)$ を 仮定して ${ }^{5)}$

5) $\left[\operatorname{diag}\left(W^{T} S_{g} V\right)\right]_{j j}=0$ となるのは, $W$ の $j$ 列の各 成分が全て 0 の場合か, $\Theta_{g} W$ すなわち等化後の能力 特性值と等化先の能力特性值 $\Theta$ の第 $j$ 次元が直交す る場合であるが，前者は (16) 式に反する。 また，後 者の場合は等化の設定に問題があると考えられる. 


$$
K=\left[\operatorname{diag}\left(W^{T} S_{g} V\right)\right]^{-1}
$$

とすると，

$$
W=V K .
$$

これを，(18) 式に再び代入すると

$K=\left[\operatorname{diag}\left(K^{T} V^{T} S_{g} V\right)\right]^{-1}=\left[\operatorname{diag}\left(V^{T} S_{g} V\right)\right]^{-1} K^{-1}$
となる. 上式を $K$ について解くと

$$
K=\left[\operatorname{diag}\left(V^{T} S_{g} V\right)\right]^{-1 / 2}
$$

であるから, 結局 $W$ は

$$
W=V K=V\left[\operatorname{diag}\left(V^{T} S_{g} V\right)\right]^{-1 / 2}
$$

となる ${ }^{6)}$ (以上). 